\title{
Ciliary Neurotrophic Factor: Pharmacokinetics and Acute-Phase Response in Rat
}

\author{
Falk Dittrich, Hans Thoenen, and Michael Sendtner
}

\begin{abstract}
Ciliary neurotrophic factor (CNTF) supports the survival of motoneurons in vitro and in vivo. Recombinant CNTF is an investigational drug for the treatment of amyotrophic lateral sclerosis. We determined the pharmacokinetics of radioiodinated CNTF after intravenous injection into rats. CNTF shows a biphasic clearance with an initial plasma half-life of 2.9 minutes and is removed from the circulation by the liver. No accumulation of radioactivity was detectable in nerve tissue or skeletal muscle after intravenous injection of $0.1 \mu \mathrm{g}$ and $0.5 \mu \mathrm{g}$ of CNTF. Radioactive degradation products accumulate in the skin. Liver cells express specific binding proteins for CNTF, and the incorporation and degradation of intravenously injected CNTF by the liver may occur after association of CNTF with the soluble CNTF receptor $\alpha$ in the circulation. Probably as a consequence of its binding to hepatocytes, CNTF induces acute-phase responses in liver. The short half-life and the inflammatory side effect may limit the clinical usefulness of systematically administered CNTF in the treatment of human motoneuron disorders.
\end{abstract}

Dittrich F, Thoenen H, Sendtner M. Ciliary neurotrophic factor: pharmacokinetics and acute-phase response in rat. Ann Neurol 1994;35:151-163

Ciliary neurotrophic factor (CNTF) has originally been identified as a potent survival factor for a variety of neuronal cell types in vitro [1], in particular, spinal motoneurons of embryonic chick and rat [2-4]. CNTF prevents the degeneration of motoneurons in vivo during embryonic development when applied onto the chorioallantoic membrane of developing chick [5], and in lesion experiments when delivered to the proximal stump of a lesioned facial nerve of newborn rats [6].

Transgenic mice lacking functional CNTF gene expression develop normally until birth but develop progressive atrophic and degenerative changes in motoneurons after the first postnatal weeks [7]. This suggests that the physiological function of CNTF might be confined to the maintenance of neuronal function in the adult rather than in survival and early differentiation of neuronal cells during development. The finding that systemically delivered CNTF is capable of preventing the degeneration and functional loss of motoneurons in the homozygous progressive motor neuronopathy (pmn) mouse mutant [8], an animal model for human spinal motoneuron disease, has raised hopes that this factor might be useful in the treatment of human degenerative disorders such as amyotrophic lateral sclerosis (ALS) [9]. However, little is known so far about the pharmacokinetics and the side effects of CNTF after systemic injection, information that is a prerequisite for potential clinical use of this compound in humans.

Endogenous expression of CNTF is found in myelinating Schwann cells of peripheral nerves as well as in a subpopulation of astrocytes, in particular, in the optic nerve and the olfactory bulb of adult rats [10]. CNTF does not share any sequence homology or similarity in biochemical properties with the members of the nerve growth factor (NGF) gene family of neurotrophic factors [11]. Predictions of the protein structure of CNTF have suggested that CNTF has a helical framework similar to leukemia inhibitory factor (LIF), oncostatin M, interleukin-6 (IL-6), and granulocyte colony-stimulating factor (G-CSF) [12]. However, CNTF differs from these molecules in that it is a cytosolic molecule that does not possess a signal peptide for secretion through the conventional endoplasmic reticulum-golgi apparatus pathway. Moreover, CNTF does not appear to be glycosylated and lacks cysteine bridges, indicating that the physicochemical properties óf CNTF could significantly differ from those of its structural relatives $[11-16]$. Therefore, pharmacokinetic data obtained in vivo for recombinant human (rh) factors like rhIL-6 [17] and rhG-CSF [18] and for murine LIF [19] might not necessarily be pertinent to CNTF.

The membrane-associated CNTF receptor complex
From the Max-Planck-Institute for Psychiatry, Department of Neurochemistry, Planegg-Martinsried, Germany.

Received May 24, 1993, and in revised form Aug 13. Accepted for publication Oct 8, 1993.
Address correspondence to Dr Sendtner, Max-Planck-Institute for Psychiatry, Department of Neurochemistry, Am Klopferspitz 18A, 82152 Planegg-Martinsried, Germany. 
appears to be composed of at least three subunits, the CNTF receptor $\alpha($ CNTFR $\alpha)$, the glycoprotein gp130, and the LIF receptor $\beta$ (LIFR $\beta$ ) (for reviews, see [2022]). The structure of CNTFR $\alpha$ has been found to be unrelated to the receptors for NGF and related neurotrophins $[23]$ but homologous to the low-affinity IL-6 receptor $\alpha(\mathrm{IL}-6 \mathrm{R} \alpha)[20-22,24]$. The expression of CNTFR $\alpha$ has been described to be mainly restricted to the nervous system and skeletal muscle [24, 25]. It was concluded from these findings that actions of CNTF after systemic administration might be restricted to these tissues. In this study we have examined the pharmacokinetics and some side effects of systemically administered CNTF in the rat.

\section{Materials and Methods \\ Animals}

Adult male Wistar rats weighing 150 to $200 \mathrm{gm}$ were used for all experiments. The rats were obtained from the breeding facilities of the Max-Planck-Institute of Biochemistry, where they are kept under specific pathogen-free conditions. Rats were supplied with food and tap water ad libitum throughout the course of the experiments. Experiments were performed in accordance with Bavarian state legislation.

\section{Radioiodination of C-terminal-modified CNTF}

Recombinant tat CNTF contains only four tyrosine residues [11] and could not be iodinated to high specific radioactivity without using large amounts of ${ }^{125} \mathrm{I}-\mathrm{Na}$ (P. Phelan, unpublished results). Therefore, a modified recombinant rat CNTF with three additional C-terminal tyrosine residues, here denoted CNTFY, was designed by adding three codons for tyrosine to the $3^{\prime}$ end of the coding region of the CDNA for rat CNTF (K. Stöckli, unpublished results), expressed in E. coli as described [26] and used for iodination. Both CNTF and CNTFY were purified from transfected E. coli using a modification of the method described by Masiakowski and colleagues [26], in which the chromatographic purification of the protein on DEAE-cellulose was replaced by a single reverse-phase, high-pressure liquid chromatography (HPLC) step on a preparative column (Vydac C4). Both CNTF and CNTFY eluted as a single peak at 50 to $55 \%$ acetonitrile with $0.1 \%$ trifluoroaceric acid, and migrated as a single band on a sodium dodecyl sulfate (SDS) containing polyacrylamide gel under reducing conditions (data not shown). The peak fractions, eluted from HPLC columns, were stored at $-70^{\circ} \mathrm{C}$ after addition of $n$-octyl- $\beta$-D-glucopyranoside (final concentration of $0.1 \%$ ). Protein concentration was determined by amino acid analysis prior to use.

Radioiodination was performed by addition of lactoperoxidase $\left(5.4 \times 10^{-13} \mathrm{~mol}\right), \mathrm{H}_{2} \mathrm{O}_{2}\left(2.3 \times 10^{-9} \mathrm{~mol}\right)$, and 0.3 mCi of ${ }^{125} \mathrm{I}-\mathrm{Na}$ to $1 \mu \mathrm{g}$ of CNTFY $\left(4.4 \times 10^{-11} \mathrm{~mol}\right)$ diluted in $50 \mu \mathrm{l}$ of $35 \mathrm{mM}$ potassium acetate at $\mathrm{pH}$. This mixture was incubated for 15 minutes at room temperature. After a further 15-minute incubation step with a second addition of $\mathrm{H}_{2} \mathrm{O}_{2}\left(2.3 \times 10^{-9} \mathrm{~mol}\right)$, the specific radioactivity of ${ }^{125} \mathrm{I}-$ CNTFY was determined by precipitating an aliquot of the reaction in $20 \%$ trichloroacetic acid (TCA) containing $0.25 \%$ bovine serum albumin (BSA) and $0.3 \% \mathrm{NaI}$, and measuring

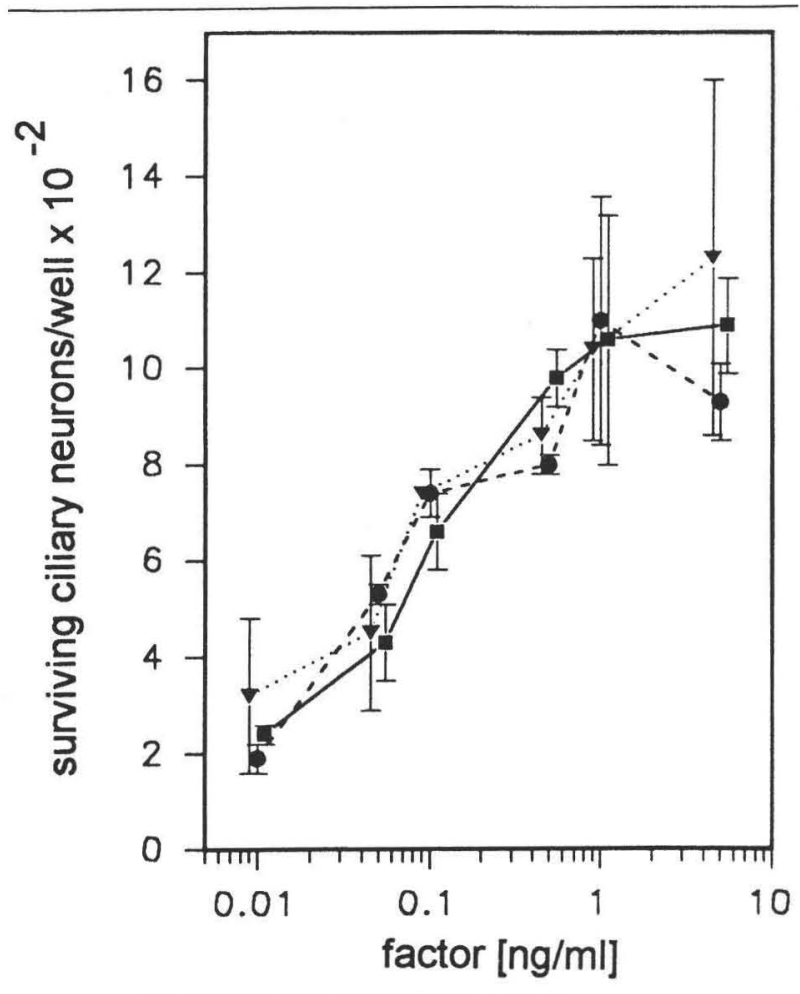

Fig 1. Biological activity of ciliary neurotrophic factor (CNTF). CNTFY (CNTF with three additional C-terminal ty rasine residues), and ${ }^{125}$ I-CNTFY. Survival of cultured embryonic day 8 cbick ciliary neurons in the presence of CNTF (-), CNTFY $(\mathbf{\nabla})$, and ${ }^{125} I-C N T F Y(\mathbf{\square})$. Surviving neurons were counted 24 bours after the addition of $10 \mathrm{pg}, 50 \mathrm{pg} .100 \mathrm{pg} .500 \mathrm{pg}$. $1 \mathrm{ng}$, or $5 \mathrm{ng}$ of factor. Each point represents the mean of two determinations; bars represent the range. For improced clarity the points for CNTFY and ${ }^{125} I-C N T F Y$ are shifted to the left and right, respectively.

the radioactivity of the precipitate. An average specific radioactivity of $1.39 \times 10^{8} \mathrm{cpm} / \mu \mathrm{g}$ was determined, which is equivalent to mean incorporation of $1.7^{125} \mathrm{I}$ per molecule of CNTFY. For further applications, free iodine was removed by size exclusion chromatography using Sephadex G-50. ${ }^{125}$ I-CNTFY was eluted with Krebs-Ringer-HEPES buffer $(\mathrm{KRH})$ at $\mathrm{pH} 7.3$, giving a concentration of 1 to $1.5 \mu \mathrm{g} / \mathrm{ml}$.

\section{Bioassay}

The chick ciliary neuron survival assay was performed as described [27]. Surviving neurons were counted after 24 hours in culture, and the factor concentration that supported halfmaximal survival of the cultured neurons was found to be 50,62 , and $70 \mathrm{pg} / \mathrm{ml}$ for CNTF, CNTFY, and ${ }^{125} \mathrm{I}$-CNTFY, respectively (Fig 1). Taking into account the variability of the assay, the biological activity of all three molecules was indistinguishable.

\section{Detection of Intravenously Injected ${ }^{125}$ I-CNTFY}

Clearance and tissue distribution of CNTF was determined after injection of 0.1 or $0.5 \mu \mathrm{g}$ of ${ }^{125} \mathrm{I}-\mathrm{CNTFY}$ in $300 \mu \mathrm{l}$ of phosphate-buffered saline (PBS) into the tail vein of ether- 
anesthetized adult male Wistar rats (150-200 gm). At different time points after injection, the rats were killed by ether overdose and blood was obtained by heart puncture. Organs were removed after perfusion with $100 \mathrm{ml}$ of PBS containing 1,000 units of heparin to remove vascular-from tissue-bound ${ }^{125}$ I-CNTFY. We chose this technique because no vascular marker was available showing identical distribution in the circulation as CNTF. The weight of wet tissue of the prepared organs was measured and the radioactivity was counted for 10 minutes in a gamma counter. Aliquots of the tissues were homogenized and precipitated in 20\% TCA to determine the extent of degradation of ${ }^{125} \mathrm{I}$-CNTFY.

\section{Autoradiography of Polyacrylamide Gels}

Discontinuous polyacrylamide gel electrophoresis (PAGE) [28] was used for further analysis of blood and tissues collected at different times after intravenous (i.v.) injection of ${ }^{125}$ I-CNTFY. For SDS-PAGE under reducing conditions the separations were performed for serum on 4 to $15 \%$ gradient gels, for liver extracts on 10 to $20 \%$ gradient gels, and for liver cell membrane proteins cross-linked to ${ }^{125} \mathrm{I}$-CNTFY on $6.5 \%$ gels. Serum was also separated by PAGE at pH 9.5 under nondenaturating conditions on 4 to $15 \%$ gradient gels prepared without SDS. The gels were dried and exposed to $\mathrm{x}$-ray films (Fuji, RX) at $-70^{\circ} \mathrm{C}$ with intensifying screens. Band intensities were determined by scanning the autoradiograms with a densitometer (Molecular Dynamics).

\section{Autoradiograpby of Tissue Sections}

At various time periods after i.v. injection of $0.1 \mu \mathrm{g}(1.94$ $\times 10^{7} \mathrm{cpm}$ ) of ${ }^{125} \mathrm{I}-\mathrm{CNTFY}$, rats were perfused with $0.01 \%$ lidocaine in PBS and subsequently with $4 \%$ paraformaldehyde in PBS. Tissues were dissected, postfixed for 2 hours, dehydrated by several washing steps with $20 \%$ sucrose in PBS, and frozen sections $(7 \mu \mathrm{m})$ were prepared. Finally, these sections were dipped in LM-1 emulsion (Amersham) and developed after at least 3 days according to manufacturer's directions. After washing, the slides were stained with hematoxylin and eosin.

\section{Cross-Linking of ${ }^{125}$ I-CNTFY In Situ}

Five minutes after i.v. injection of $0.5 \mu \mathrm{g}\left(7.1 \times 10^{7} \mathrm{cpm}\right)$ of ${ }^{125} \mathrm{I}$-CNTFY, rats were killed by ether overdose and 10 $\mathrm{ml}$ of $\mathrm{KRH}$ containing the cross-linking agent 1-ethyl-3-(3dimethylaminopropyl)carbodiimide (EDC) at a concentration of $300 \mathrm{mM}$ was injected into the liver via the portal vein. After 20 minutes of incubation on ice, $5 \mathrm{ml}$ of $1 \mathrm{M}$ glycine in PBS was injected via the portal vein to stop the reaction. The liver was removed and minced in homogenization buffer at $\mathrm{pH} 7.4$ containing sucrose $(0.25 \mathrm{mM}), \mathrm{NaHCO}_{3}(1 \mathrm{mM})$, $\mathrm{MgCl}_{2}$ (2 mM), glycine (1 M), phenylmethylsulfonyl fluoride $(1 \mathrm{mM})$, aprotinin $(1.5 \mu \mathrm{M})$, and leupeptin $(2.4 \mu \mathrm{M})$ with a glass-glass homogenizer by 15 strokes at $500 \mathrm{rpm}$. Cell membranes were pelleted by centrifuging the homogenate (10 minutes, $1,000 \mathrm{~g}$ at $4^{\circ} \mathrm{C}$ ). The pellet was washed once with homogenization buffer and the membranes were further purified by two-polymer phase partitioning as described [29]. The interphase was lysed in Tris-buffered saline at $\mathrm{pH} 7.4$ containing $1 \%$ Nonidet P-40 and $10 \%$ glycerol, and insoluble residues were removed by centrifugation for 5 minutes at $12,000 \mathrm{~g}$. The supernatant was separated by SDS-PAGE and analyzed by autoradiography.

\section{Northern Blot Analysis of Acute-Phase Response}

Recombinant rat CNTF was lyophilized after dilution in a buffer suitable for i.v. injection in humans (Elomel, Boehringer) containing $0.25 \% \mathrm{BSA}$ (Sigma) with a low endotoxin content. When redissolved in pyrogen-free water, the CNTF showed no loss of biological activity (data not shown). CNTF was injected i.v. in a volume of $300 \mu \mathrm{l}$ as described above, and after different time points the liver was removed from the killed rat and chilled in liquid nitrogen. RNA was extracted with guanidinium-thiocyanate and further purified by isopyknic gradient centrifugation in cesium trifluoroacetate [30]. Fifteen micrograms of total RNA were electrophoresed through $1.2 \%$ agarose gels containing formaldehyde (2 M) and vacuum-blotted to nylon membranes (Hybond-N, Amersham). Hybridization was performed overnight at $42^{\circ} \mathrm{C}$ as described $[10]$ with $5 \times 10^{6} \mathrm{cpm} / \mathrm{ml}$ of a radioactive random prime-labeled cDNA probe for human haptoglobin [31]. Haptoglobin is induced as an acute-phase protein both in human and rat [32]. Rat haptoglobin shows $75 \%$ and $82 \%$ amino acid sequence identity with the $\alpha$ - and $\beta$-subunits of the human haptoglobin allele one gene product [33]; at the cDNA level, the sequence identity for the $\beta$-subunit is approximately $78 \%$ [34]. After washing two times in $2 \times$ saline-sodium citrate (SSC) containing $0.1 \%$ SDS at room temperature and once for 30 minutes in $0.1 \times$ SSC containing $0.5 \% \mathrm{SDS}$ at $50^{\circ} \mathrm{C}$, the blots were exposed to $\mathrm{x}$-ray films (Fuji, RX) at $-70^{\circ} \mathrm{C}$ with intensifying screens. Band intensities were determined by scanning the autoradiograms with a densitometer (Molecular Dynamics).

\section{Results \\ Clearance from the Blood of Intravenously Injected ${ }^{125}$ I-CNTFY}

Following i.v. injection of $0.1 \mu \mathrm{g}\left(1 \times 10^{7} \mathrm{cpm}\right)$ of ${ }^{125}$ I-CNTFY, approximately $75 \%$ of the radioactivity was removed from the circulation within 10 minutes. The initial half-time of clearance $\left(t_{0.5}\right)$ of ${ }^{125} \mathrm{I}$-CNTFY from the blood was 2.9 minutes, while the subsequent decrease of ${ }^{125}$ I-CNTFY levels in the blood was less rapid $\left(t_{0.5}, 4 \mathrm{hr}\right.$ ) (Fig 2$)$. The highest tissue concentrations of ${ }^{125}$ I-CNTFY 10 minutes after i.v. injection were found in the liver $\left(6.88 \pm 0.23 \times 10^{5} \mathrm{cpm} / \mathrm{gm}\right.$ of tissue) (Fig 3a), indicating that about $70 \%$ of the injected radioactivity has accumulated in this organ (total wet weight of liver, $11.5 \mathrm{gm}$ ). At the same time, the levels of radioactivity in the urine were still very low, and the kidneys contained only about $7 \%$ of the injected radioactivity $\left(3.86 \pm 0.4 \times 10^{5} \mathrm{cpm} / \mathrm{gm}\right.$ of wet tissue), confirming that the rapid removal of ${ }^{125} \mathrm{I}-$ CNTFY from the circulation within the first $10 \mathrm{~min}$ utes occurred via the liver rather than by renal clearance. At 6 hours after i.v. injection, more than $70 \%$ of the total amount of injected radioactivity was detectable in the skin. Thus, removal of ${ }^{125} \mathrm{I}-\mathrm{CNTFY}$ and its radioactive degradation products by renal clearance 


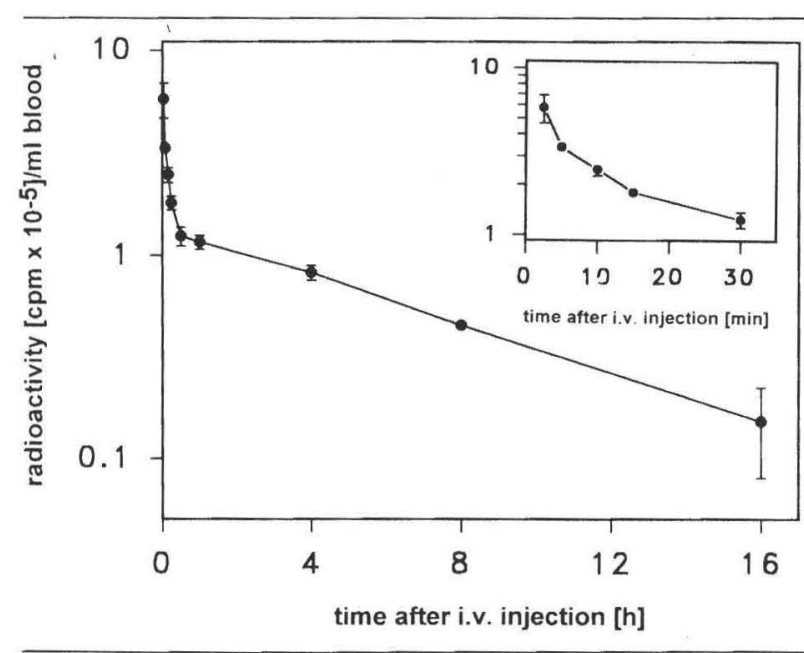

Fig 2. Clearance of intravenously injected ${ }^{125}$ I-CNTFY from rat blood. At different time points $(2.5 \mathrm{~min}$ to $16 \mathrm{br})$ after injection of $0.1 \mu \mathrm{g}\left(1 \times 10^{7} \mathrm{cpm}\right)$ of ${ }^{125} \mathrm{I}$-CNTFY into the tail vein of male Wistar rats (150-200 gm), blood was collected by heart puncture and radioactivity was measured. Each point represents the mean of determinations from 3 or 4 rats. The insert shows the same data from 2.5 minutes to 30 minutes after injection only. Error bars represent the standard deviation (SD). Two elimination phases with plasma half-lives for ${ }^{125} I$ CNTFY of 2.9 minutes and 4 bours, respectively, were obtained by best curve fitting using the GraFit program.

seems to play only a minor role in removing the radioactivity from the circulation also during the second slower clearance phase. Indeed, levels of measurable radioactivity in the urine were quite low $\left(0.4 \times 10^{5}\right.$ $\mathrm{cpm} / 50 \mu \mathrm{l}$ at 10 minutes, $1.7 \times 10^{5} \mathrm{cpm} / 50 \mu \mathrm{l}$ at 60 minutes, and $0.3 \times 10^{5} \mathrm{cpm} / 50 \mu \mathrm{l}$ at 3 hours after i.v. injection), suggesting that less than $10 \%$ of the injected radioactivity is removed by renal clearance within 3 hours after i.v. injection of ${ }^{125} \mathrm{I}-\mathrm{CNTFY}$.

\section{Binding Proteins for ${ }^{I 25}$ I-CNTFY in the Blood}

The autoradiograms of serum samples collected within 1 hour after i.v. injection of $0.1 \mu \mathrm{g}\left(1 \times 10^{7} \mathrm{cpm}\right)$ of ${ }^{125} \mathrm{I}-\mathrm{CNTFY}$ and separated by SDS-PAGE showed a predominant ${ }^{125} \mathrm{I}-\mathrm{CNTFY}$ band and two much fainter bands at $45 \mathrm{kd}$ and $14 \mathrm{kd}$, respectively (Fig 4a, lane S). During the first hour after i.v. injection the intensity of all three bands decreased, but no further radioactive band appeared that might result from potential degradation fragments of ${ }^{125}$ I-CNTFY (see Fig 4a). By running the same serum samples on a nondenaturating polyacrylamide gel, it became apparent that after i.v. injection ${ }^{125}$ I-CNTFY is associated with two plasma proteins (Fig 4b). Most of the i.v. injected ${ }^{125} \mathrm{I}-\mathrm{CNTFY}$ was bound to the smaller plasma protein. ${ }^{125} \mathrm{I}-\mathrm{CNTFY}$ bound to this protein could be detected by autoradiography at a relative migration position corresponding to the 94-kd protein phosphorylase $b .{ }^{125} \mathrm{I}-\mathrm{CNTFY}$
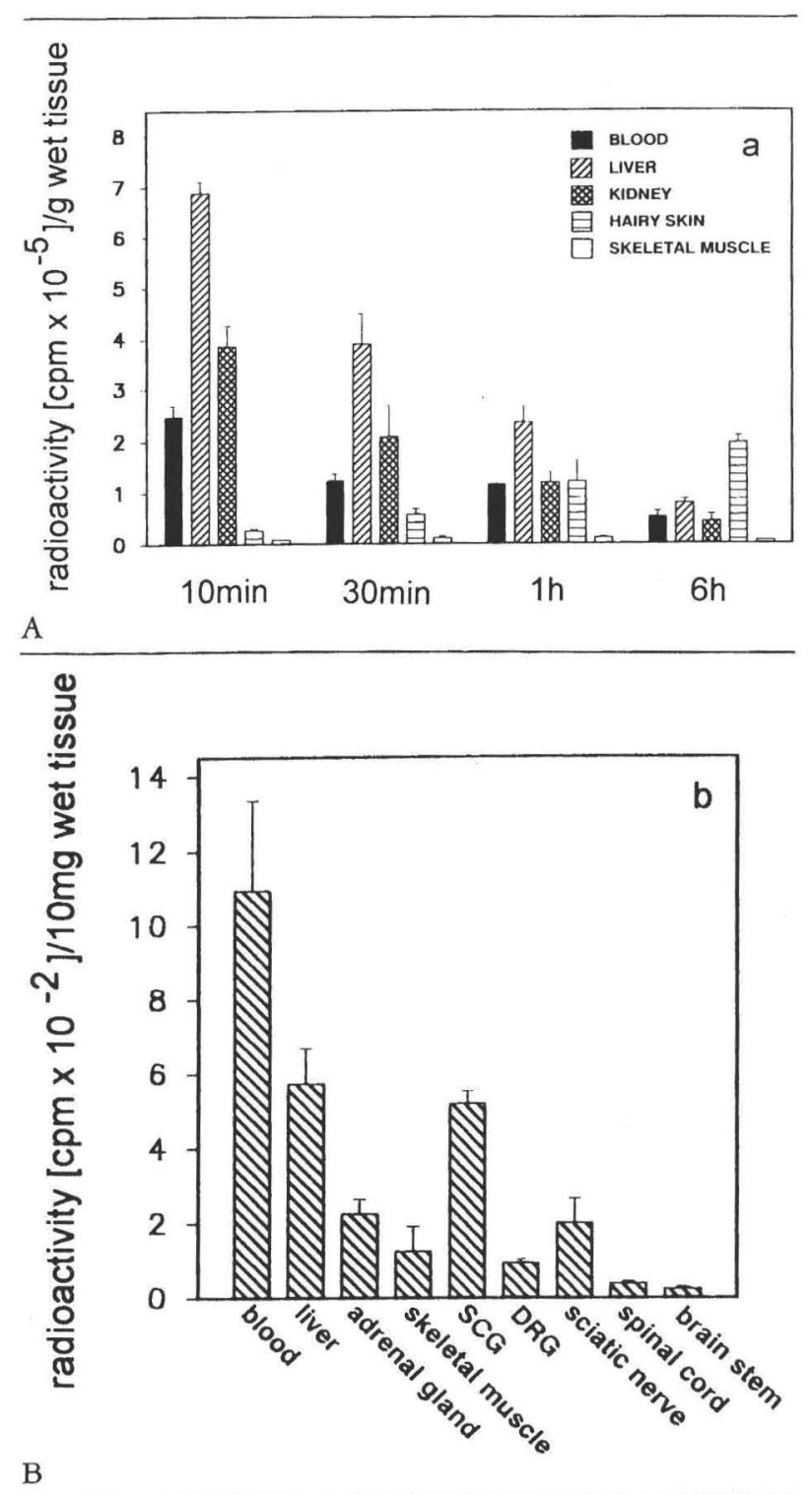

Fig 3. Tissue distribution of radioactivity after intravenous injection of ${ }^{125}$ I-CNTFY ${ }^{125}$ I-labeled ciliary neurotrophic factor with three additional C-terminal tyrosine residues) in rat. At different time points after injection of ${ }^{125} I-C N T F Y$ into the tail vein of male Wistar rats $(150-200 \mathrm{gm})$, the specific radioactivity in different organs was measured (A) 10 minutes to 6 bours after injection of $0.1 \mu \mathrm{g}\left(1.13 \times 10^{7} \mathrm{cpm}\right)$ and (B) 12 hours after injection of $0.5 \mu \mathrm{g}\left(7.2 \times 10^{7} \mathrm{cpm}\right)$ of ${ }^{125} I-C N T F Y$. Data represent the mean of determinations from 3 , to 4 rats and error bars represent the $S D$. 

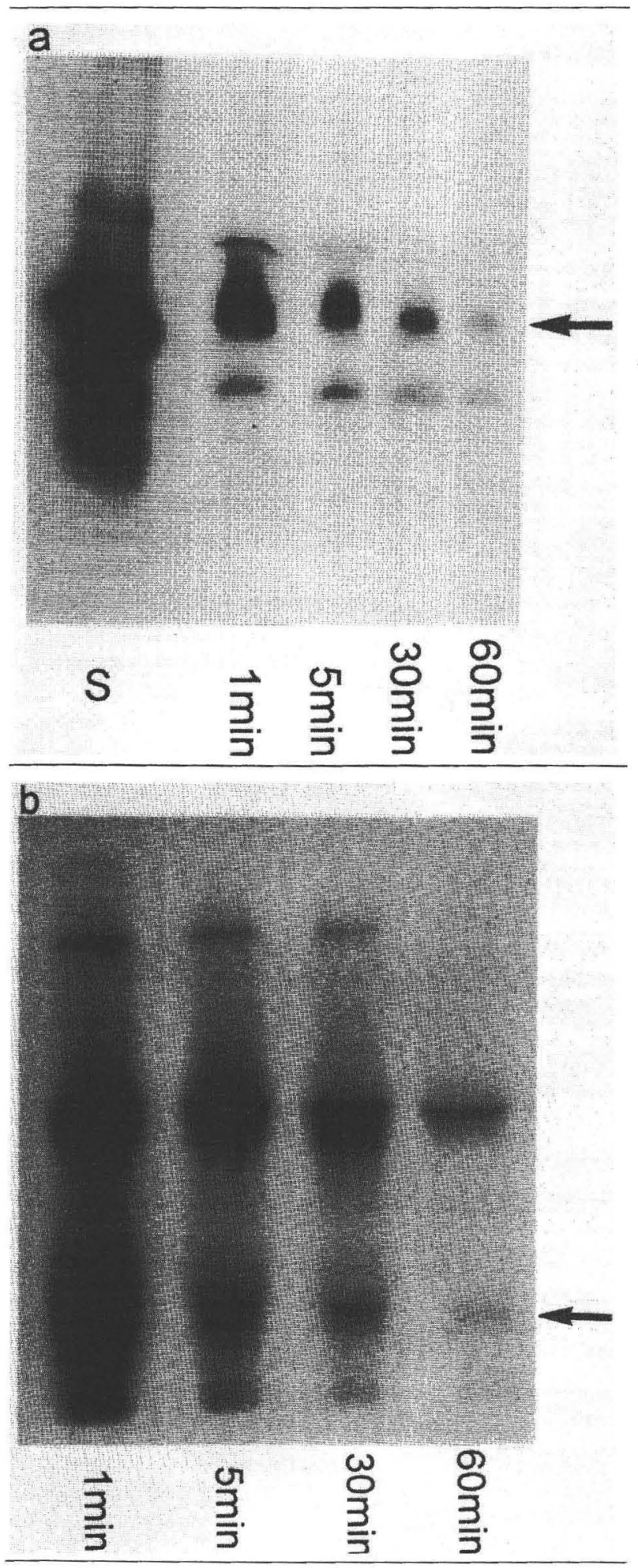

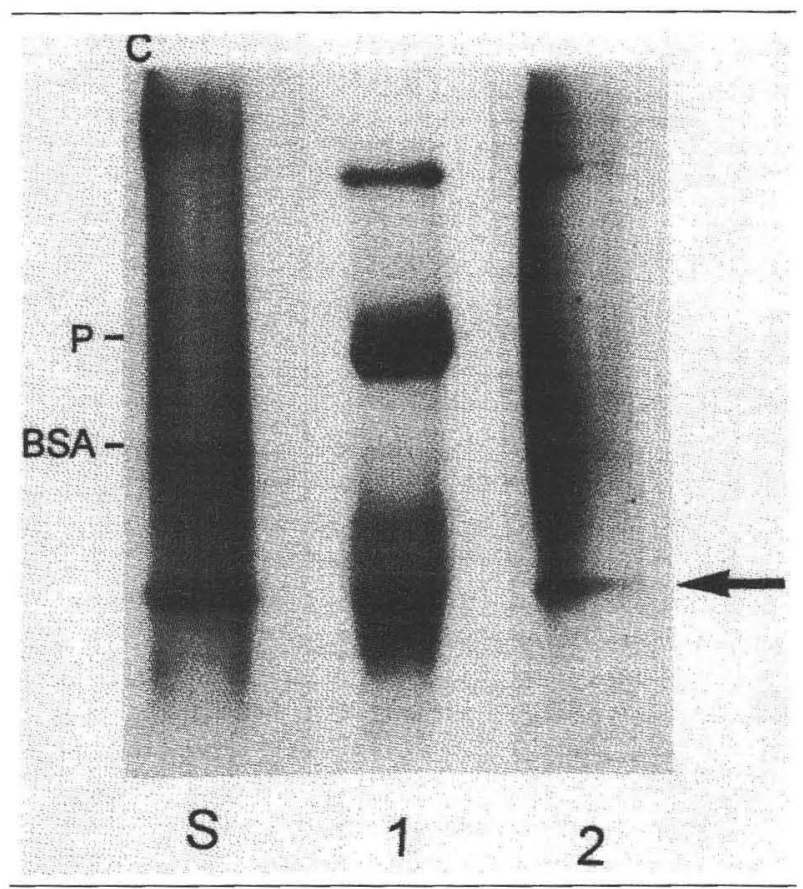

Fig 4. Fate of ${ }^{125}$ I-CNTFY ${ }^{125}$ I-labeled ciliary neurotropbic factor $\left({ }^{125} I-C N T F\right)$ with three additional C-terminal tyrosine residues) in rat blood after intravenous injection. Serum obtained at indicated time points after injection of $0.1 \mu \mathrm{g}(1 \times$ $10^{7}(\mathrm{pm})$ of ${ }^{125} \mathrm{I}$-CNTFY into the tail vein of male Wistar rats $(150-200 \mathrm{gm})$ was separated on polyacrylamide gels and analyzed by autoradiography. The arrow marks the ${ }^{125} I-C N T F Y$ band. (a) Sodium dodecyl sulfate-polyacrylamide gel electrophoresis (SDS-PAGE) under reducing conditions of 60- $\mu$ l serum aliquots using a 10 to $20 \%$ gradient gel; $S=$ aliquot of ${ }^{125} \mathrm{I}$ CNTFY solution $\left(300 \mathrm{pg}, 3 \times 10^{4} \mathrm{cpm}\right)$ prior to injection; the 45-kd and the 14-kd band are dimers and degradation products of ${ }^{125}$ I-CNTFY respectively, as determined by western blot analysis with different CNTF-peptide antisera (data not shown); exposure time $=2$ days. (b) $P A G E$ under nondenaturating conditions of 20- $\mathrm{ul}$ serum aliquots using a 4 to $15 \%$ gradient gel. (c) PAGE under nondenaturating conditions using a 4 to $15 \%$ gradient gel; prior to electrophoresis. $10 \mu \mathrm{g}$ of cytochrome $\mathrm{c}$ was loaded in all lanes to increase the protein concentration; bovine serum albumin (BSA; $67 \mathrm{kd}$ ) and phosphorylase $\mathrm{b}(P ; 94 \mathrm{kd})$ were run on the same gel and their indicated location was determined by staining with Coomassie Blue; $S=$ aliquot of ${ }^{125} \mathrm{I}-\mathrm{CNTFY}$ solution $\left(260 \mathrm{pg}, 2.6 \times 10^{4} \mathrm{cpm}\right)$ prior to injection; lane $1=20-\mu l$ serum aliquot obtained 5 minutes after intravenous injection of ${ }^{125}$ I-CNTFY; lane $2=2.5 \mu \mathrm{g}$ of buman $\alpha_{2}$-macroglobulin (Sigma $M-7151$ ) was incubated for 1 bour at $37^{\circ} \mathrm{C}$ with $1 \mathrm{ng}$ of ${ }^{125} \mathrm{I}-\mathrm{CNTFY}$ in $10 \mu \mathrm{l}$ of $20 \mathrm{mM}$ sodium phosphate buffer at $\mathrm{pH} 7.4$, and an aliquot of $2 \times 10^{4} \mathrm{cpm}$ was used for electrophoresis. 
associated with the larger plasma protein migrates to the same position as ${ }^{125} \mathrm{I}$-CNTFY bound to human $\alpha_{2^{-}}$ macroglobulin $\left(\alpha_{2} \mathrm{M}\right)$ (Fig $\left.4 \mathrm{c}\right)$.

\section{Tissue Distribution of ${ }^{125}$ I-CNTFY after Intravenous Injection}

During the first hour after i.v. injection of $0.1 \mu \mathrm{g}$ or 0.5 $\mu g$ of ${ }^{125}$ I-CNTFY, the highest tissue concentrations of ${ }^{125}$ I-CNTFY were detected in the liver. The levels of specific radioactivity in the liver declined during the following 6 hours to a similar low level as in the blood. During this time period, the levels of specific radioactivity in the skin increased gradually to levels that were higher than those in the liver (see Fig 3a). Unexpectedly, spinal cord, brain, and skeletal muscle, tissues that are all known to express relatively high amounts of the CNTFR $\alpha$ mRNA [24, 25], did not show any accumulation of radioactivity within 6 hours after i.v. injection of ${ }^{125}$ I-CNTFY (see Fig 3a). Twelve hours after i.v. injection, levels of radioactivity in $10 \mathrm{mg}$ of desanguinated skeletal muscle were less than $15 \%$ of those detectable in $10 \mu \mathrm{l}$ of blood. In the nervous system, relatively high levels of specific radioactivity were found only in the superior cervical ganglion (SCG) $(500 \mathrm{cpm} / 10 \mathrm{mg}$ of tissue) and sciatic nerve (200 cpm/10 mg of tissue), while the dorsal root ganglia contained less than $130 \mathrm{cpm} / 10 \mathrm{mg}$ of tissue. Autoradiograms of spinal cord and brainstem did not show any accumulation of radioactivity (data not shown). Indeed, the levels of specific radioactivity in these tissues were less than $40 \mathrm{cpm} / 10 \mathrm{mg}$ (see Fig $3 \mathrm{~b}$ ), corresponding to maximally 0.28 pg of intact ${ }^{125} \mathrm{I}-$ CNTFY per $10 \mathrm{mg}$ of tissue, which is equivalent to not more than one trophic unit per gram of tissue.

\section{Degradation of ${ }^{125}$ I-CNTFY by Liver Cells}

To study the fate of ${ }^{125} \mathrm{I}$-CNTFY in the liver after i.v. injection, we separated liver homogenates by SDSPAGE. Two major bands were detectable by autoradiography, an upper band, corresponding to ${ }^{125} \mathrm{I}-$ CNTFY, and a lower band at $14 \mathrm{kd}$, which is about 10 times less intensive and already detectable in the ${ }^{125}$ I-CNTFY preparation after radioiodination (Fig 5). Between 1 and 3 hours after i.v. injection the intensity of the ${ }^{125} \mathrm{I}$-CNTFY band declined significantly (more

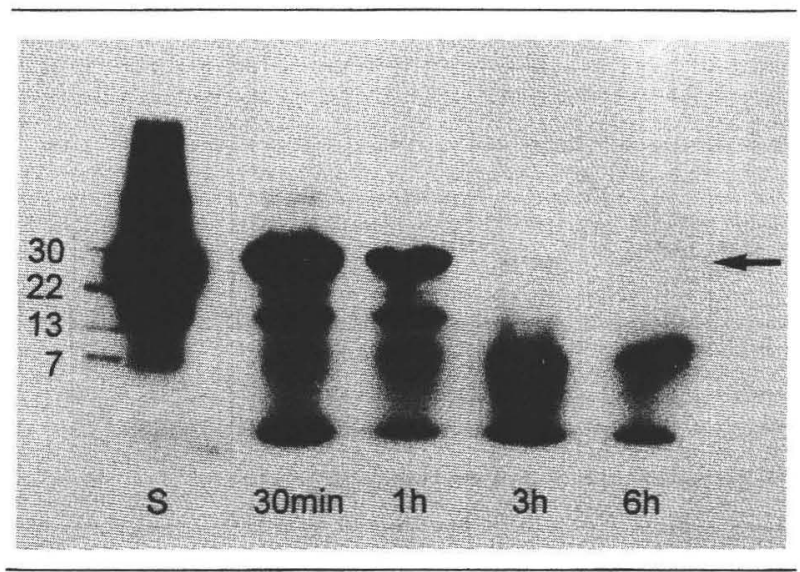

Fig 5. Degradation of intravenously injected ${ }^{125}$ I-CNTFY ${ }^{125}$ I-labeled ciliary neurotrophic factor with three additional Cterminal tyrosine residues) in rat liver. Liver was excised at different time points after injection of $0.1 \mu \mathrm{g}\left(1.77 \times 10^{7} \mathrm{cpm}\right)$ of ${ }^{125}$ I-CNTFY into the tail vein of male Wistar rats (150$200 \mathrm{gm}$ ), homogenized, and the bomogenate separated by sodium dodecyl sulfate-polyacrylamide gel electrophoresis on a 10 to $20 \%$ gradient gel under reducing conditions and analyzed by autoradiography (exposure time $=2$ weeks). Size of molecular mass markers is indicated in kilodaltons; the arrow marks the ${ }^{125}$ I-CNTFY band; $S=$ aliquot of ${ }^{125}$ I-CNTFY solution 134 $\mathrm{pg}, 6 \times 10^{3} \mathrm{cpm}$ ) prior to injection; the less intense $45-\mathrm{kd}$ and the 14-kd bands in lane $S$ are discussed in Figure 4.

than $80 \times$ ), whereas the total radioactivity in the liver was reduced only $1.7 \times$. Simultaneously, a band at 7 $\mathrm{kd}$ (presumably representing a proteolytic fragment of ${ }^{125}$ (-CNTFY) increased in intensity. At 6 hours after injection, most of the ${ }^{125} \mathrm{I}$-CNTFY appeared to be degraded, and the presumptive 7-kd proteolytic fragment represented the dominant band. Consistent with this observation, only $21 \%$ of the radioactivity in liver, taken 6 hours after i.v. injection of ${ }^{125}$ I-CNTFY and subsequently homogenized, could be precipitated in $20 \%$ TCA. Prior to injection, it was possible to precipitate $95 \%$ of the radioactivity from the ${ }^{125}$ I-CNTFY solution (Table). We could not analyze skin homogenates by SDS-PAGE because their level of radioactivity was too low. However, 6 hours after i.v. injection of ${ }^{125} \mathrm{I}$-CNTFY, only $9 \%$ of the total radioactivity in skin could be precipitated (see Table). These data indicate that the accumulated radioactivity in skin (see Fig

Tricbloroacetic Acid-precipitable Radioactivity in Different Tissues 6 Hours after Injection of $0.1 \mu \mathrm{g}\left(1.13 \times 10^{7} \mathrm{cpm}\right)$ of ${ }^{125}$ I-CNTFY into the Tail Vein of Male Wistar Rats (150-200 gm)

\begin{tabular}{llll}
\hline & $\begin{array}{l}\text { Radioactivity } \\
\left(\left[\mathrm{cpm} \times 10^{-5}\right] / \mathrm{gm} \text { wet tissue }\right)\end{array}$ & $\begin{array}{l}\text { TCA-precipitable } \\
(\%)\end{array}$ & $\begin{array}{l}\text { Non-TCA-precipitable } \\
(\%)\end{array}$ \\
\hline 125I-CNTFY & & 95 & 5 \\
$\quad$ solution & - & 74 & 26 \\
Adrenal gland & 0.14 & 21 & 79 \\
Liver & 0.78 & 9 & 91 \\
Hairy skin & 1.95 & 9 & \\
\hline
\end{tabular}

${ }^{125} \mathrm{I}$-CNTFY $={ }^{125}$ I-labeled ciliary neurotrophic factor with three additional C-terminal tyrosine residues. 
3a) can be attributed primarily to breakdown products of ${ }^{125} \mathrm{I}$-CNTFY. In contrast, in adrenal gland $74 \%$ of the tissue bound radioactivity could be precipitated by TCA 6 hours after i.v. injection of ${ }^{125}$ I-CNTFY (see Table), suggesting that a major proportion of the radioactivity measured represents intact ${ }^{125} \mathrm{I}-\mathrm{CNTFY}$.

\section{Binding Sites of ${ }^{125} I-C N T F Y$ on Liver Cells}

Autoradiograms of liver sections 1 hour after i.v. injection of $0.1 \mu \mathrm{g}\left(1.94 \times 10^{7} \mathrm{cpm}\right)$ of ${ }^{125}$ I-CNTFY, when most of the factor was not expected to be degraded (see Fig 5), showed an accumulation of silver grains over the cytoplasm and its compartments but not over the nuclei of rat liver cells (Fig 6). This indicates that a significant proportion of the i.v. injected ${ }^{125}$ I-CNTFY is taken up into the hepatocytes.

To analyze whether the accumulation of i.v. injected ${ }^{125}$ I-CNTFY in liver cells results from the interaction with specific CNTF binding sites, we performed crosslinking studies to liver cells in situ with ${ }^{125} \mathrm{I}$-CNTFY (Fig 7). To do this we injected $0.5 \mu \mathrm{g}\left(7.1 \times 10^{7} \mathrm{cpm}\right)$ of ${ }^{125} \mathrm{I}$-CNTFY into the tail vein and 5 minutes later, the cross-linking agent EDC into the portal vein of male Wistar rats (150-200 gm). At that time a high amount of ${ }^{125}$ I-CNTFY has already accumulated in the liver and, if bound to membrane proteins, would be expected to be cross-linked to them under the conditions used. Following cross-linking, SDS-PAGE of purified liver cell membrane proteins gave three bands of cross-linked proteins detectable by autoradiography at 99,140 , and $235 \mathrm{kd}$.

\section{Biological Effects of CNTF in the Liver after Intravenous Injection}

Recently, it has been shown that recombinant rat CNTF increases mRNA levels of acute-phase proteins in hepatocytes in vitro $[31,35]$. The accumulation of ${ }^{125}$ I-CNTFY in liver after i.v. injection (see Fig 3a) raises the question as to whether CNTF also induces acute-phase responses in vivo. To investigate this, the level of haptoglobin mRNA in the liver was determined by northern blot analysis after i.v. injection of CNTF (Fig 8). Time course analysis showed that the level of haptoglobin mRNA in the liver reaches a maximum 8 hours after i.v. injection of $10 \mu \mathrm{g}$ of CNTF (Fig 8a). The level of haptoglobin mRNA in CNTFtreated rats at this time was significantly greater by a factor of 2.3 (Student's $t$ test, $p=0.005 ; \mathrm{n}=5$ ) than in control rats injected with the same volume of buffer (Fig 8c). Also 6 hours after i.v. injection of $10 \mu \mathrm{g}$ of CNTF, a more than $2 \times$ higher haptoglobin mRNA level was detectable in comparison with control rats (Fig 8b). Furthermore, the increase of haptoglobin mRNA level 6 hours after i.v. injection of CNTF was dose dependent (Fig 8d). These results indicate that the effects of CNTF on hepatocytes are not confined
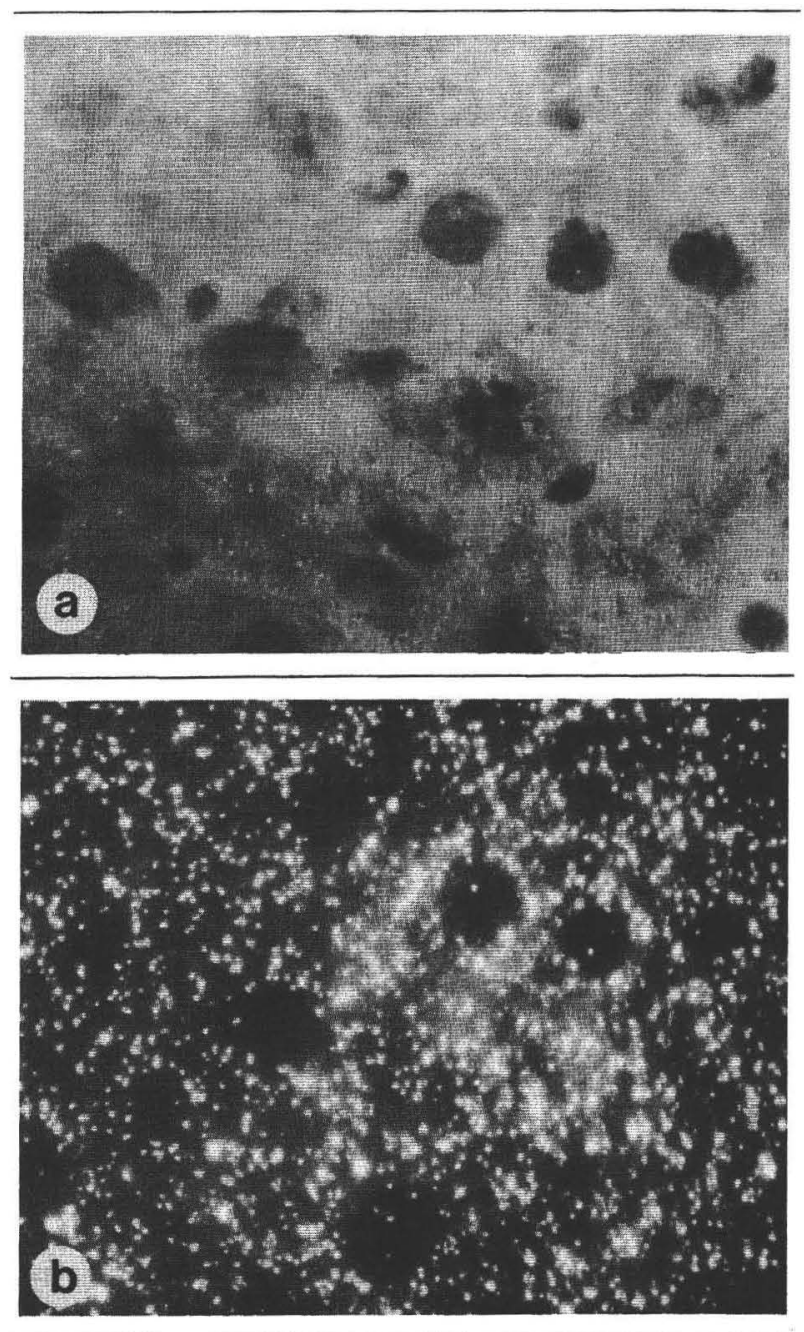

Fig 6. Distribution of ${ }^{125}$ I-CNTFY ${ }^{125}$ I-labeled ciliary neurotrophic factor with three additional C-terminal tyrosine residues) in rat liver cells after intravenous injection. One hour after injection of $0.1 \mu \mathrm{g}\left(1.94 \times 10^{7} \mathrm{cpm}\right)$ of ${ }^{125} \mathrm{I}-\mathrm{CNTFY}$ into the tail vein of male Wistar rats $(150-200 \mathrm{gm})$, the liver was perfused in situ with phosphate-buffered saline (PBS) and subsequently with $4 \%$ paraformaldebyde in PBS. After postfixation and dehydration 7- $\mu m$ frozen sections were prepared and analyzed by autoradiography as described in Materials and Methods. Bright-field (a) and dark-field (b) photomicrographs revealed the accumulation of silver grains over the cytoplasm and its compartments but not over the nuclei of rat liver cells. ( $\times 400$ before $22 \%$ reduction.)

to cultured cells but also occur in vivo after pharmacological administration of CNTF.

\section{Discussion}

To be of therapeutic value in the treatment of degenerative motoneuron disease, CNTF should be accessible to motoneurons, for example via their endplates, where proteins are taken up from the circulation [36]. Therefore, we studied the pharmacokinetics of CNTF after i.v. injection. For our experiments we used iodin- 


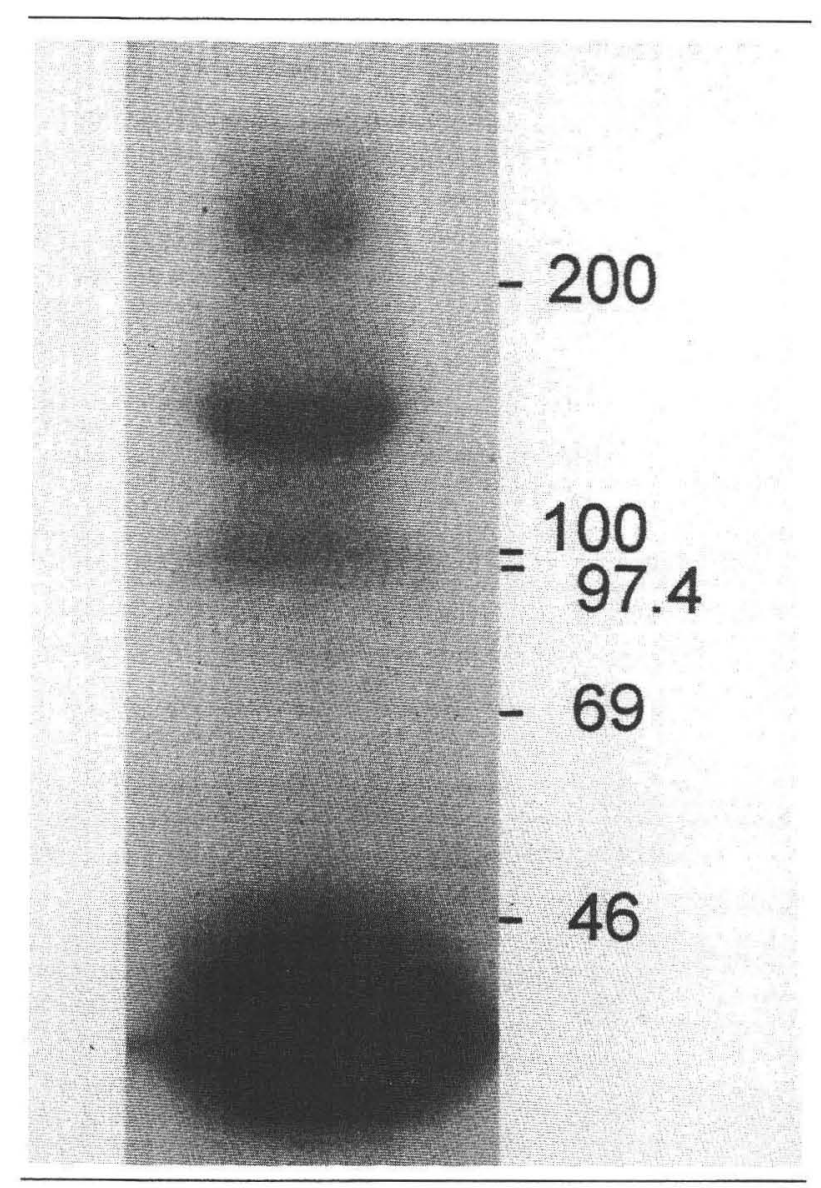

Fig 7. Cross-linking of ${ }^{125}$ I-CNTFY ${ }^{125}$ I-labeled ciliary neurotrophic factor with three additional C-terminal tyrosine residues) to membrane proteins of rat liver cells in situ. Five minutes after injection of $0.5 \mu \mathrm{g}\left(7.1 \times 10^{7} \mathrm{cpm}\right)$ of ${ }^{125} \mathrm{I}-\mathrm{CNTFY}$ into the tail vein of a male Wistar rat $(200 \mathrm{gm}) 10 \mathrm{ml}$ of Krebs-Ringer-HEPES buffer containing the cross-linking agent 1-etbyl-3-(3-dimetbylaminopropyl)carbodiimide (300 $\mathrm{mM}$ ) was injected into its portal vein. Membrane proteins were purified from liver, separated by sodium dodecyl sulfate-polyacrylamide gel electrophoresis under reducing conditions on a $6.5 \% \mathrm{gel}$, and finally analyzed by autoradiography. Size of molecular mass markers is indicated in kilodaltons.

ated, C-terminally modified recombinant rat CNTF ( ${ }^{125}$ I-CNTFY), whose biological activity in the chick ciliary neuron assay was indistinguishable from unmodified CNTF (see Fig 1). Intravenously injected ${ }^{125} \mathrm{I}$ CNTFY shows biphasic clearance kinetics with a fast initial phase (see Fig 2) similar to the kinetics of rhIL-6 after i.v. injection into rats [17], of rhG-CSF injected i.v. into humans [37] and of murine recombinant LIF i.v. injected into mice [19]. We could not decide from our results whether the two deduced elimination phases of ${ }^{125}$ I-CNTFY would best be described as $\alpha$ and $\beta$-phases or $\beta$ - and $\gamma$-phases of drug elimination. For experimental reasons blood sampling by heart puncture was not possible earlier than 2.5 minutes after i.v. injection into the tail vein. Thus, if the first elimination phase of ${ }^{125}$ I-CNTFY occurred before this time, it would not be detected in our experiments.

Corresponding experiments with unlabeled recombinant rat CNTF detected in serum by a two-site enzyme-linked immunosorbent assay [38] have shown similar results. Also in this experimental paradigm, the initial plasma half-life of CNTF was shorter than 10 minutes, suggesting that the rapid disappearance of radioactivity from the blood is not due to cleavage of the C-terminal ${ }^{125} \mathrm{I}$-tyrosine residues from the ${ }^{125} \mathrm{I}-\mathrm{CNTFY}$ molecule or to deiodination.

Analysis of the tissue distribution of ${ }^{125} \mathrm{I}-\mathrm{CNTFY}$ after i.v. injection revealed a correlation between the fast elimination from the blood (see Fig 2) and the accumulation of ${ }^{125}$ I-CNTFY in the liver (see Fig 3a). This situation is similar to that observed for the structurally related compound IL-6. Most of this factor $(80 \%)$ is taken up by the liver 20 minutes after i.v. injection into rats $[17]$. In contrast, for LIF, another structural analogue of CNTF, the fast elimination after i.v. injection into mice has been shown to be due to clearance by the kidneys [19]. Our data suggest that bolus i.v. injection might be inadequate for clinical CNTF administration because it leads to poor bioavailability of CNTF for motoneurons. Moreover, these results might also have implications for subcutaneous injection of CNTF. Although long-term serum levels of proteins after subcutaneous injection might be higher than those after i.v. injection, as was shown for rhG-CSF [18], a significant proportion of subcutaneously injected CNTF would pass the liver once it has entered the bloodstream. Thus, other manners of CNTF application should be considered (see below).

That the elimination of i.v. injected ${ }^{125}$ I-CNTFY by the kidneys apparently does not play a major role in the clearance of this factor suggests that ${ }^{125} \mathrm{I}-\mathrm{CNTFY}$ might bind to plasma proteins. PAGE analysis under nondenaturating conditions shows the binding of ${ }^{125} \mathrm{I}$ CNTFY to two distinct plasma proteins (see Fig $4 \mathrm{~b}$ ). The smaller plasma protein seems to have a molecular mass of less than $100 \mathrm{kd}$.

Recently, soluble CNTFR $\alpha$ (sCNTFR $\alpha$ ), which has a molecular mass of $68 \mathrm{kd}$, has been detected in human cerebrospinal fluid and blood plasma [39]. Thus, it is tempting to speculate that the smaller plasma protein shown in Figure 3b, binding most of the ${ }^{125} \mathrm{I}-\mathrm{CNTFY}$, could be sCNTFR $\alpha$. SDS-PAGE analysis under reducing conditions of the same blood samples revealed either that ${ }^{125} \mathrm{I}-\mathrm{CNTFY}$ is not degraded after i.v. injection in the blood, at least not during the first hour after injection (see Fig 4a), or that its fragments are removed from the circulation immediately after degradation. In contrast, a radiolabeled 7-kd polypeptide was detectable in liver extracts, which progressively increased in relative intensity compared with the ${ }^{125}$ I-CNTFY band during the first 6 hours, during which time the intensity 

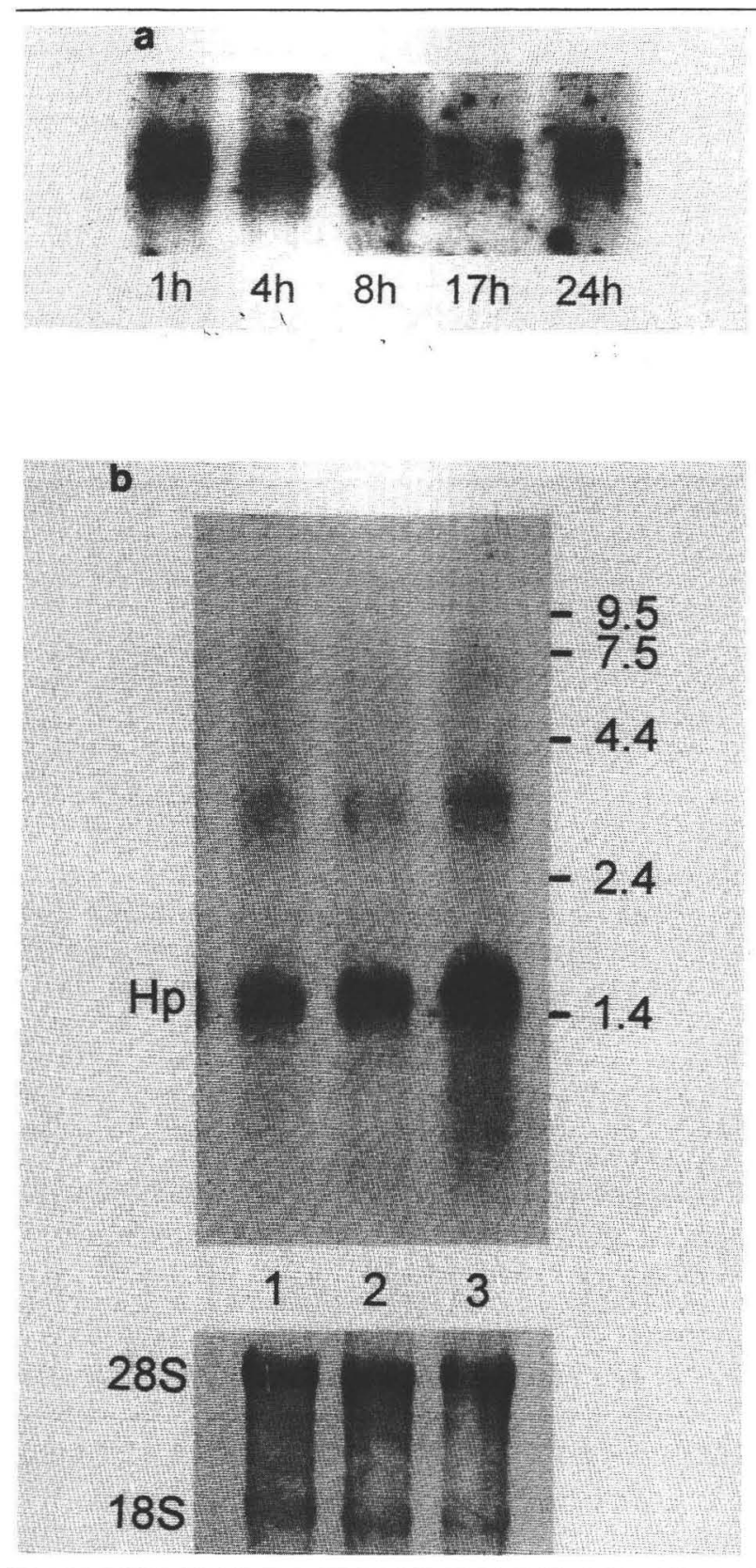

Fig 8. Stimulation of haptoglobin gene expression in rat liver by ciliary neurotrophic factor (CNTF). Recombinant rat CNTF was diluted in buffer (see Materials and Methods), lyophilized, redissolved in pyrogen-free water, and injected into the tail vein of ether-anesthetized male Wistar rats (150-200 gm). At different times after injection, total RNA was extracted from liver and subjected to nortbern blot analysis. The filters were bybridized with a radioactive random prime-labeled cDNA probe for buman baptoglobin and the resultant autoradiograms scanned for densitometric analysis. $H p=$ baptoglobin $m R N A$. (a) Time course of haptoglobin $m R N A$ level after injection of $10 \mu \mathrm{g}$ of 'CNTF. (b) Six hours after injection of $10 \mu \mathrm{g}$ of CNTF (lane 3) the level of haptoglobin $m R N A$ was $3.1 \times$ bigher than in noninjected control rats (lane 1 ) and $2.2 \times$ higher than in rats injected with the same volume of buffer only (lane 2); size of

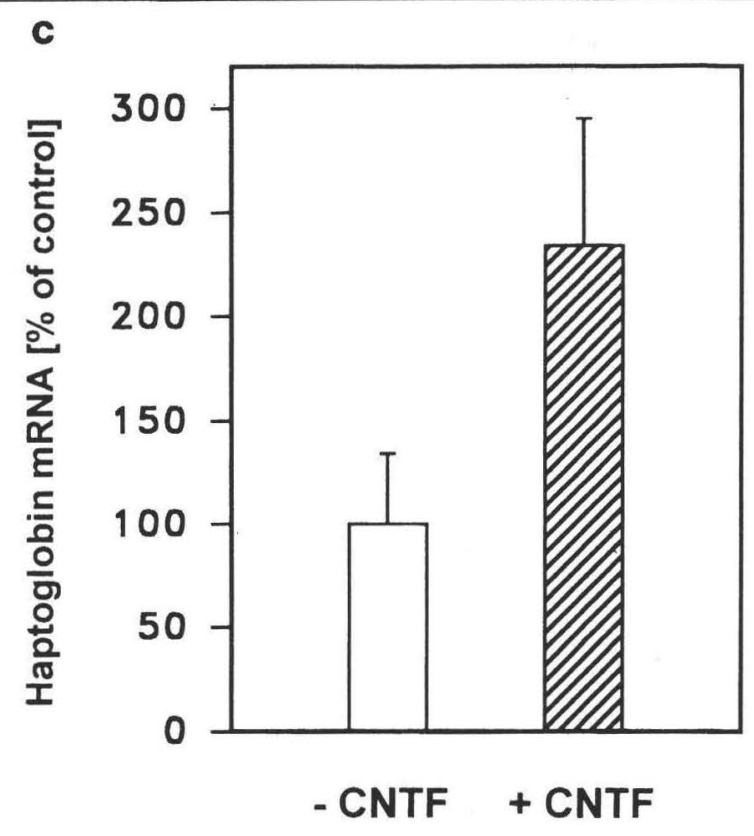

d

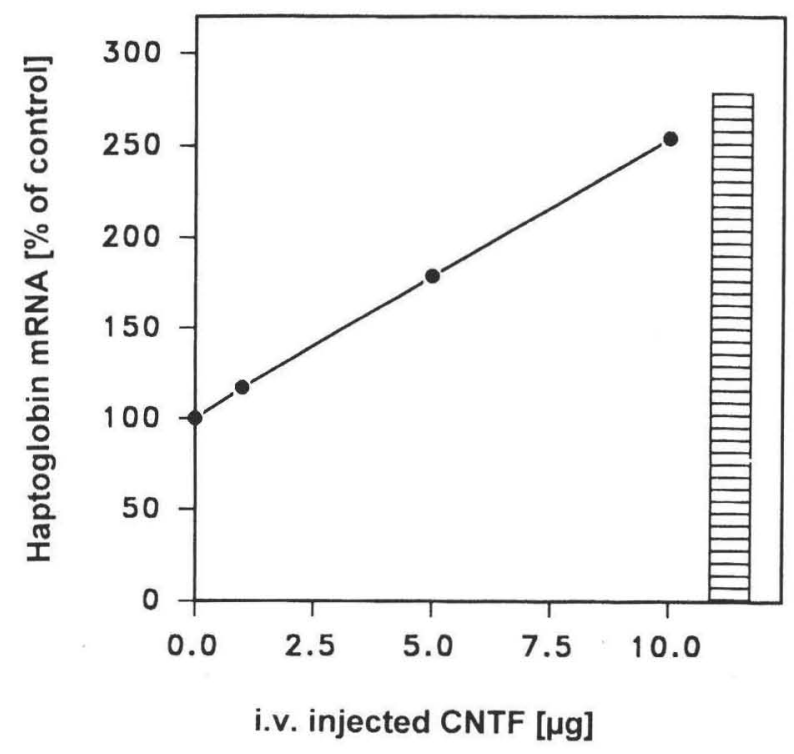

RNA markers is indicated in kilobases; $28 S$ rRNA and $18 \mathrm{~S}$ rRNA were stained with methylene blue on the blot to demonstrate that the same amounts of total RNA were loaded in each lane (lower panel). (c) Increase in haptoglobin $m R N A$ level at 8 bours after injection of $10 \mu \mathrm{g}$ of CNTF (+CNTF) by a factor of 2.3 in comparison with control rats injected with the same volume of buffer only ( $-C N T F)$; statistical significance tested by Student's t test: $\mathrm{p}=0.005 ; n=5$ in each group.

(d) Dose-response correlation between haptoglobin $m R N A$ level and the amount of CNTF injected at 6 hours after injection. The basal baptoglobin $m R N A$ level (set to 100\%) was determined from rats injected with the same volume of buffer only. The bar represents the haptoglobin $m R N A$ level in rats 24 bours after intramuscular injection of $250 \mu \mathrm{l}$ of turpentine, as a positive control. 
of the ${ }^{125}$ I-CNTFY band decreased (see Fig 5). The $7-\mathrm{kd}$ polypeptide may be a proteolytic fragment of ${ }^{125} \mathrm{I}-$ CNTFY. Many proteins, including IL- 6 and NGF have been shown to be protected from proteolysis after binding to $\alpha_{2} \mathrm{M}$ in the blood $[40,41]$. Correspondingly, the larger plasma protein, which binds ${ }^{125} \mathrm{I}$ CNTFY (see Fig 4b), might be $\alpha_{2} \mathrm{M}$. In support of this hypothesis, we found that ${ }^{125} \mathrm{I}-\mathrm{CNTFY}$, associated with the larger plasma protein, migrates to the same position as ${ }^{125} \mathrm{I}-\mathrm{CNTFY}$ bound to human $\alpha_{2} \mathrm{M}$ (see Fig 4c).

The accumulation of ${ }^{125} \mathrm{I}$-CNTFY in the liver after i.v. injection was surprising, as CNTFR $\alpha$, the primary CNTF binding site on CNTF-responsive cells [42], was not expected in high amounts in this organ according to the reported levels of CNTFR $\alpha$ mRNA [24, 25]. However, high amounts of cell membraneassociated CNTFR $\alpha$ might not be necessary for the accumulation of ${ }^{125} \mathrm{I}$-CNTFY in the liver, if one assumes that most of the i.v. injected CNTF becomes associated with sCNTFR $\alpha$ in the blood. The ${ }^{125} \mathrm{I}$ CNTFY/sCNTFR $\alpha$ complex might then bind in the liver to other subunits of the CNTF receptor complex associated with the cell membrane $[39,43]$ and present on liver cells (Fig 9 as a model of CNTF disposition after i.v. injection). Under these assumptions, the accumulation of CNTF in liver would require that these other subunits are highly expressed in cells of this organ.

The cell membrane-associated CNTF receptor complex has been suggested to be composed of at least three subunits, CNTFR $\alpha$, gp 130, and LIFR $\beta$ [20-22, $39,43,44]$. The glycoprotein gp130 has been shown to transduce the CNTF signal, most likely together with at least one other component, which might be the LIFR $\beta[22,39,43,44]$, and to be highly expressed by liver cells [25]. Therefore, binding of a ${ }^{125}$ I-CNTFY/ sCNTFR $\alpha$ complex to gp130 might mediate the accumulation of ${ }^{125} \mathrm{I}-\mathrm{CNTFY}$ in the liver. The model of the cell membrane-associated CNTF receptor complex is consistent with our results obtained by cross-linking of ${ }^{125}$ I-CNTFY to liver in situ (Fig 7). Taking into account a molecular mass of $23 \mathrm{kd}$ for ${ }^{125} \mathrm{I}$-CNTFY, we observed a cross-linked protein of $76 \mathrm{kd}$ on liver cells, which is the expected size of the rat CNTFR $\alpha[24,39]$. It has been proposed that on primary rat hepatocytes, CNTF binds to the IL-6R $\alpha$ [35], which has a molecular mass of approximately $80 \mathrm{kd}$ [32]. However, CNTF does not bind to the soluble IL-6R $\alpha$, and a hepatoma cell line lacking the IL-6R $\alpha$ responds to CNTF [31]. Therefore, it is highly likely that ${ }^{125}$ I-CNTFY is crosslinked to rat liver cells (i.e., predominately hepatocytes) in situ to CNTFR $\alpha$. Two other bands detectable after cross-linking of ${ }^{125} \mathrm{I}$-CNTFY to liver cells in situ showed relative molecular masses of about $140 \mathrm{kd}$ and $235 \mathrm{kd}$ (see Fig 7). The molecular mass of gp130 expressed on a rat sympathoadrenal progenitor cell line

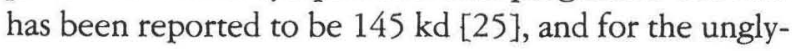

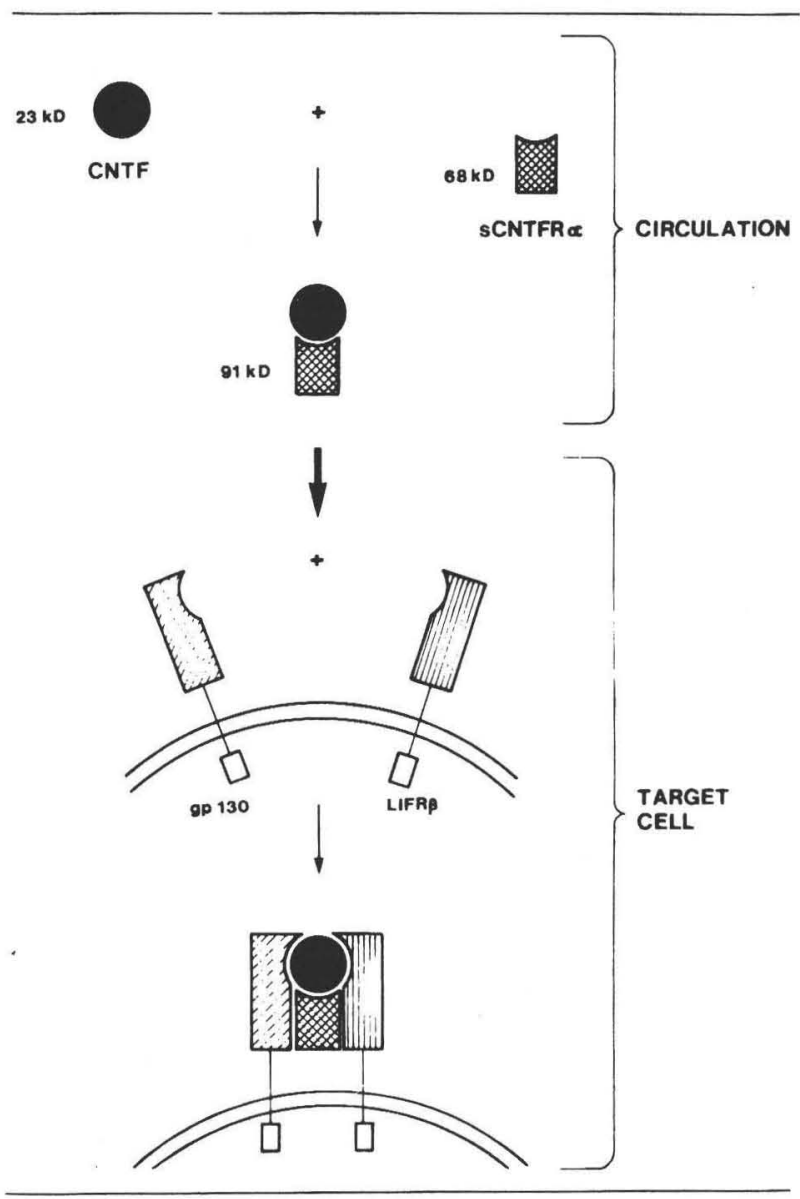

Fig 9. Model of ciliary neurotrophic factor (CNTF) disposition after intravenous (i.v.) injection. After i.v. injection CNTF becomes associated with the soluble CNTF receptor $\alpha$ (sCNTFR $\alpha$ ) in the circulation. On the cell membrane of liver cells and other $C N T F$-responsive cells in vivo, the CNTF/sCNTFR $\alpha$ complex associates with gp130 and LIFR $\beta$ to form a functional CNTF receptor complex.

cosylated human form of gp130, a molecular mass of $101 \mathrm{kd}$ has been determined $[45,46]$. Therefore, the cross-linked band of $140 \mathrm{kd}$ could result from ${ }^{125} \mathrm{I}-$ CNTFY bound to gp130 being tissue-specifically glycosylated to a lesser extent than in neuronal cells. The 235-kd band could represent ${ }^{125}$ I-CNTFY cross-linked to the LIFR $\beta$, as the molecular mass of the glycosylated form of the human placental LIFR $\beta$ is $190 \mathrm{kd}$ [47]. Thus, on liver cells, the initial steps of signal transduction following CNTF binding may be identical to those described for neuronal cell lines [44] and for an erythroleukemia cell line [43].

Six hours after i.v. injection of ${ }^{125}$ I-CNTFY, radioactivity accumulated in the hairy skin, the tissue with the highest specific radioactivity at this time point (Fig 3a). This is strikingly similar to the tissue distribution of ${ }^{125}$ I-rhIL-6 after i.v. injection in the rat: At 5 hours, the radioactivity attributable to ${ }^{125}$ I-rhIL-6 in liver had de- 
clined significantly and high levels were found in skin, which radioactivity was suggested to be degradation products of ${ }^{125}$ I-rhIL-6 generated by fibroblasts [48]. In contrast, our results indicate that the degradation of ${ }^{125}$ I-CNTFY has already taken place in the liver (see Fig 5), and that the radioactivity accumulated in the fat cells of the hairy skin (data not shown) does not represent intact ${ }^{125} \mathrm{I}$-CNTFY, but breakdown products (see Table).

Our data suggest that ${ }^{125}$ I-CNTFY does not accumulate in skeletal muscle after systemic administration (see Fig 3a). Even 12 hours after injection, the specific radioactivity detectable in skeletal muscle was lower than that of either liver, adrenal gland, or the SCG (see Fig 3b). This seems to be at odds with the reported high abundance of CNTFR $\alpha$ mRNA in skeletal muscle $[24,25]$. Recently, it was suggested that, after nerve injury, a significant proportion of the CNTFR $\alpha$ produced in skeletal muscle is released into the circulation [39]. If this also happens in unlesioned animals, i.v. injected CNTF might bind to soluble and not cell membrane-associated CNTFR $\alpha$ in skeletal muscle. Preferential accumulation of ${ }^{125} \mathrm{I}-\mathrm{CNTFY} / \mathrm{sCNTFR} \alpha$ complex in the liver rather than in skeletal muscle may thus be due to a relatively high expression of gp 130 protein on the surface of liver cells, to which the ${ }^{125} \mathrm{I}$ CNTFY/sCNTFR $\alpha$ complex might bind.

A side effect of CNTF after systemic application is the increase of haptoglobin gene expression in the liver (see Fig 8). Haptoglobin is an acute-phase protein [49], whose gene expression is increased by CNTF in a human hepatoma cell line [31]. Stimulation of acutephase responses by recombinant human cytokines were also observed in vitro with primary hepatocytes and hepatoma cell lines for IL-6 [50], LIF [51], and oncostatin M [52], and in vivo for IL-6 [53, 54]. Therefore, one might assume that there are similar signaling pathways for these effects in hepatic cells. Indeed, the receptors of these cytokines are members of a hematopoietic cytokine receptor family $[20,55]$, which use gp130 for signal transduction $[43,45,56,57]$. Recently, gp130 was also described as being involved in CNTF signal transduction in neuronal cells $[43,44]$, as well as in an erythroleukemia cell line [43]. Our data concerning the cross-linking of ${ }^{125} \mathrm{I}$-CNTFY to membrane proteins of liver cells in situ (see Fig 7) suggest that gp130 and LIFR $\beta$ are involved in the initial CNTF signal transduction for the induction of acute-phase response in hepatocytes. Further experiments are required to determine whether CNTF and LIF, which are believed to use the same initial signal transduction pathways (for reviews, see $[21,22]$ ), induce identical patterns of acute-phase proteins in liver.

Taken together, our results indicate that systemic injection of CNTF might not lead to optimal availabil- ity to motoneurons, the target cells for the clinical use of CNTF in motoneuron disease. Most i.v. injected CNTF is taken up (see Fig 3a) and degraded (Fig 4) by the liver. Not more than one trophic unit of ${ }^{125} \mathrm{I}$ CNTFY per gram of tissue could be detected in the spinal cord 12 hours after i.v. injection of $0.5 \mu \mathrm{g}$ of ${ }^{125}$ I-CNTFY. Even under optimal diffusion conditions such as in cell culture, one trophic unit of CNTF would elicit only half-maximal response on neuronal survival. As CNTF is a protein of 200 amino acids, low diffusion within the extracellular space is expected to prevent the majority of CNTF from binding to its specific neuronal receptors. Correspondingly, previous experiments have shown that about 500 trophic units per milliliter of blood are necessary to improve motor function in pmn mice $[8,38]$, an animal model of human motoneuron disease.

Even if positive results with systematically administered CNTF were obtained in ALS patients, our results indicate that optimization of CNTF delivery will be necessary to obtain maximal therapeutic benefit. One way to improve the bioavailability of compounds to the central nervous system (CNS) and nerve roots is intrathecal injection [58, 59]. Alternatively, it might be necessary to use gene therapeutic approaches $[60$, 61] to provide increased concentrations of CNTF within the CNS at its sites of action, i.e., motoneurons in the spinal cord and regions within the CNS containing upper motoneurons.

In addition, side effects of systemically administered CNTF on hepatocytes might further limit this therapeutical approach. From our study, we would predict the induction of acute-phase proteins as a side effect of CNTF in patients treated with pharmacological doses of this factor. However, quantitative toxicological data relevant to the use of CNTF in patients can only be obtained from clinical trials.

This work was supported by grants from the Schilling Stiftung im Forscherverband der Deutschen Industrie.

We thank Dr E. Mehl and Mrs J. Plambeck for amino acid analysis of the CNTF preparations and Dr S. Rose-John for the human haptoglobin cDNA clone. We gratefully acknowledge the support of Regeneron Pharmaceuticals. We also thank Drs P. Carroll, J. Huber, R. A. Hughes, and K. V. Toyka for helpful discussions and critically reading the manuscript.

\section{References}

1. Barbin G, Manthorpe M, Varon S. Purification of the chick eye ciliary neuronotrophic factor. J Neurochem 1984;43:14681478

2. Arakawa Y, Sendtner M, Thoenen $H$. Survival effect of ciliary neurotrophic factor (CNTF) on chick embryonic motoneurons in culture: comparison with other neurotrophic factors and cytokines. J Neurosci 1990;10:3507-3515

3. Magal E, Burnham P, Varon S. Effects of ciliary neurotrophic 
factor on rat spinal cord neurons in vitro: survival and expression of choline acetyltransferase and low-affinity nerve growth factor receptors. Dev Brain Res 1991;63:141-150

4. Martinou J-C, Martinou I, Kato AC. Cholinergic differentiation factor (CDF/LIF) promotes survival of isolated rat embryonic motoneurons in vitro. Neuron 1992;8:737-744

5. Oppenheim RW, Prevette D, Qin-Wei Y, et al. Control of embryonic motoneuron survival in vivo by ciliary neurotrophic factor. Science 1991;252:1616-1618

6. Sendtner M, Kreutzberg GW, Thoenen H. Ciliary neurotrophic factor prevents the degeneration of motor neurons after axotomy. Nature 1990;345:440-441

7. Masu J, Wolf E, Holtmann B, et al. Disruption of the CNTF gene results in motor neuron degeneration. Nature 1993;365: $27-32$

8. Sendtner M, Schmalbruch H, Stöckli KA, et al. Ciliary neurotrophic factor prevents degeneration of motor neurons in mouse mutant progressive motor neuropathy. Nature 1992;358:502504

9. Oppenheim RW. High hopes of a trophic factor. Nature 1992; 358:451-452

10. Stöckli KA, Lillien LE, Näher-Noé M, et al. Regional distribution, developmental changes, and cellular localization of CNTFmRNA and protein in the rat brain. J Cell Biol 1991;115:447459

11. Stöckli KA, Lottspeich F, Sendtner M, et al. Molecular cloning, expression and regional distribution of rat ciliary neurotrophic factor. Nature 1989;342:920-923

12. Bazan JF. Neuropoietic cytokines in the hematopoietic fold. Neuron 1991;7:1-20

13. Gough NM, Williams L. The pleiotropic actions of leukemia inhibitory factor. Cancer Cells 1989;1:77-80

14. Nagata S. Gene structure and function of granulocyte colonystimulating factor. Bio Essay 1989;10:113-117

15. Van Snick J. Interleukin-6: an overview. Annu Rev Immunol 1990;8:253-278

16. Rose TM, Bruce AG. Oncostatin M is a member of a cytokine family that includes leukemia-inhibitory factor, granulocyte colony-stimulating factor, and interleukin 6. Proc Natl Acad Sci U S A 1991;88:8641-8645

17. Castell JV, Geiger T, Gross V, et al. Plasma clearance, organ distribution and target cells of interleukin-6/hepatocytestimulating factor in the rat. Eur J Biochem 1988;177:357-361

18. Tanaka H, Okada Y, Kawagishi M, Tokiwa T. Pharmacokinetics and pharmacodynamics of recombinant human granulocytecolony stimulating factor after intravenous and subcutaneous administration in the rat. J Pharmacol Exp Ther 1992;251: 1199-1203

19. Hilton DJ, Nicola NA, Waring PM, Metcalf D. Clearance and fate of leukemia-inhibitory factor (LIF) after injection into mice. J Cell Physiol 1991;148:430-439

20. Taga T, Kishimoto T. Cytokine receptors and signal transduction. FASEB J 1992;6:3387-3396

21. Ip NY, Yancopoulos GD. Ciliary neurotrophic factor and its receptor complex. Prog Growth Factor Res 1992;4:139-155

22. Davis S, Yancopoulos GD. The molecular biology of the CNTF receptor. Curr Opin Neurobiol 1993;3:20-24

23. Meakin SO, Shooter EM. The nerve growth factor family of receptors. Trends Neurosci 1992;15:323-331

24. Davis S, Aldrich TH, Valenzuela DM, et al. The receptor for ciliary neurotrophic factor. Science 1991;252:59-63

25. Ip NY, McClain J, Barrezueta NX, et al. The $\alpha$ component of the CNTF receptor is required for signaling and defines potential CNTF targets in the adult and during development. Neuron 1993;10:89-102

26. Masiakowski P, Liu H, Radziejewski C, et al. Recombinant hu- man and rat ciliary neurotrophic factors. J Neurochem 1991;57: 1003-1012

27. Hughes SM, Lillien LE, Raff MC, et al. Ciliary neurotrophic factor induces type- 2 astrocyte differentiation in culture. Nature 1988;335:70-73

28. Hames BD. An introduction to polyacrylamide gel electrophoresis. In: Hames $\mathrm{BD}$, Rickwood D, eds. Gel electrophoresis of proteins: a practical approach. Oxford: IRL Press, 1981:1-91

29. Evans WH. Organelles and membranes of animal cells. In: Findlay JBC, Evans WH, eds. Biological membranes: a practical approach. Oxford: IRL Press, 1987:1-35

30. Okayama $\mathrm{H}$, Kawaichi M, Brownstein M, et al. High-efficiency cloning of full-length cDNA; construction and screening of cDNA expression libraries for mammalian cells. Methods Enzymol 1987;154:3-28

31. Schooltink H, Stoyan T, Roeb E, et al. Ciliary neurotrophic factor induces acute-phase protein expression in hepatocytes. FEBS Lett 1992;314:280-284

32. Heinrich PC, Castell JV, Andus T. Interleukin- 6 and the acute phase response. Biochem J 1990;265:621-636

33. Marinkovic S, Baumann $H$. Structure, hormonal regulation, and identification of the interleukin- 6 and dexamethasoneresponsive element of the rat haptoglobin gene. Mol Cell Biol 1990;10:1573-1583

34. Goldstein LA, Heath EC. Nucleotide sequence of rat haptoglobin cDNA. J Biol Chem 1984;259:9212-9217

35. Nesbitt JE, Fuentes NL, Fuller GM. Ciliary neurotrophic factor regulates fibrinogen gene expression in hepatocytes by binding to the interleukin- 6 receptor. Biochem Biophys Res Commun 1993;190:544-550

36. Fishman PS, Farrand DA, Kristt DA. Penetration and internalization of plasma proteins in the human spinal cord. J Neurol Sci 1991;104:166-175

37. Morstyn G, Campbell L, Souza LM, et al. Effect of granulocyte colony stimulating factor on neutropenia induced by cytotoxic chemotherapy. Lancet 1988;26:667-671

38. Sendtner M, Dittrich F, Hughes RA, Thoenen H. Actions of CNTF and neurotrophins on degenerating motoneurons: preclinical studies and clinical implications. J Neurol Sci 1994 (in press)

39. Davis S, Aldrich TH, Ip NY, et al. Released form of CNTF receptor $\alpha$ component as a soluble mediator of CNTF responses. Science 1993;259:1736-1739

40. Matsuda T, Hirano T, Nagasawa S, Kishimoto T. Identification of $\alpha_{2}$-macroglobulin as a carrier protein for IL- 6 . J Immunol 1989; $142: 148-152$

41. James K. Interactions between cytokines and $\alpha_{2}$-macroglobulin. Immunol Today 1990;11:163-166

42. Squinto SP, Aldrich TH, Lindsay RM, et al. Identification of functional receptors for ciliary neurotrophic factor on neuronal cell lines and primary neurons. Neuron 1990;5:757-766

43. Taga T, Narazaki M, Yasukawa K, et al. Functional inhibition of hematopoietic and neurotrophic cytokines by blocking the interleukin 6 signal transducer gp130. Proc Natl Acad Sci U S A 1992;89:10998-11001

44. Ip NY, Nye SH, Boulton TG, et al. CNTF and LIF act on neuronal cells via shared signaling pathways that involve the IL- 6 signal transducing receptor component gp130. Cell 1992;69: $1-20$

45. Taga T, Hibi M, Hirata Y, et al. Interleukin- 6 triggers the association of its receptor with a possible signal transducer, gp130. Cell 1989;58:573-581

46. Hibi M, Murakami M, Saito M, et al. Molecular cloning and expression of an IL-6 signal transducer, gp130. Cell 1990;63: $1149-1157$

47. Gearing DP, Thut CJ, VandenBos T, et al. Leukemia inhibitory 
factor receptor is structurally related to the IL- 6 signal transducer, gp 130. EMBO J 1991;10:2839-2848

48. Castell J, Klapproth J, Gross V, et al. Fate of interleukin-6 in the rat. Eur J Biochem 1990;189:113-118

49. Koj A. Detinition and classification of acute-phase proteins. In: Dingle JT. Gordon JL, eds. Research monographs in cell and tissue phrsiology, vol. 10. Amsterdam: Elsevier, 1985:139-144

50. Andus T. Geiger T. Hirano T, et al. Recombinant human B cell stimulatory factor 2 (BSF-2/IFN- $\beta 2$ ) regulates $\beta$-fibrinogen and albumin mRNA levels in Fao-9 cells. FEBS Lett 1987;221: $18-22$

51. Baumann H, Wong GG. Hepatocyte-stimulating factor III shares structural and functional identity with leukemia-inhibitory factor. J Immunol 1989;143:1163-1167

52. Richards CD, Brown TJ, Shoyab M, et al. Recombinant oncostatin M stimulates the production of acute phase proteins in HepG2 cells and rat primary hepatocytes in vitro. J Immunol 1992;148:1731-1736

53. Geiger T, Andus T, Klapproth J, et al. Induction of rat acutephase proteins by interleukin 6 in vivo. Eur J Immunol 1988;18: $717-721$

54. Marinkovic S, Jahreis GP, Wong GG, Baumann H. IL-6 modu- lates the synthesis of a specific set of acute phase plasma proteins in vivo. J Immunol 1989;142:808-812

55. Bazan JF. Structural design and molecular evolution of a cytokine receptor superfamily. Proc Natl Acad Sci U S A 1990;87: 6934-6938

56. Gearing DP, Comeau MR, Friend DJ, et al. The IL-6 signal transducer, gp 130: oncostatin $\mathrm{M}$ receptor and affinity converter for the LIF receptor. Science 1992;255:1434-1437

57. Liu J, Modrell B, Aruffo A, et al. Interleukin- 6 signal transducer gpl30 mediates oncostatin M signaling. J Biol Chem 1992;267: $16763-16766$

58. Ochs G, Struppler A. Treatment of spasticity by implantable drug administration devices and intrathecal catheter. In: Motor disturbances I. London: Academic Press, 1987:199-209

59. Kroin JS, Penn RD. Implantable pumps to deliver drugs into the CNS. In: Neuwelt EA, ed. Implications of the blood-brain barrier and its manipulation, vol 2, clinical aspects. New York: Plenum Medical, 1989:601-615

60. Anderson WF. Human gene therapy. Science 1992;256:808813

61. Gage F, Christen Y, eds. Gene transfer and therapy in the nervous system. Heidelberg: Springer-Verlag, 1992 